conductivity and viscosity depend on temperature, the equations representing the distribution of velocity and temperature near the solid surface are complicated. W. F. Cope summarizes the results of calculations which he made with D. R. Hartree, and gives numerical examples illustrating the difference between these calculations and the earlier ones of Pohlhausen. The measurement of the temperature of low-density gases moving at high speeds presents considerable difficulties. If the gas is slowed down and a thermocouple is placed in a region of slow flow, the temperature there can be corrected to give the temperature in the fast-moving gas ; but the heat transfer from the gas to the thermocouple is so slow that the measured temperatures lag behind the true temperatures. J. E. P. Dunning describes a thermometer in which gas is forced to flow over a thermocouple at sonic speed by applying suction to a pipe surrounding it. This measures nearly the same temperature as the slow-flow thermometer but suffers much less from thermal lag.

Recent progress in the problem of knock in internal combustion engines is described by Sir Alfred Egerton and N. P. W. Moore. Comparatively simple conceptions like those evoked to explain the experiments of Tizard and Pye cannot explain what is observed when an engine knocks. Chemical actions take place during the compression stroke which 'pre-sensitize' gas which has not yet been touched by the combustion flame. Antiknock compounds affect this gas but do not affect the rate of propagation of the combustion flame. A simple method for measuring the conductivity of liquids is described by E. F. M. van der Held and F. G. van Drunen. This method is useful for corrosive liquids which would damage apparatus commonly used for measuring heat conductivity.

Vol. 4 contains forty-three papers on dynamics, experimental methods and numerical computations. The subjects range from the use of matrices for calculating oscillations of complex elastic structures to papers on the strength of reinforced plastics and a description of a 50-ton dead-weight standard of load for calibrating testing machines. An interesting paper by L. S. Wasserman compares accelerations measured at points on the wing tips and other parts of an aeroplane while landing with accelerations computed theoretically from known elastic characteristics of the machine. Diagrams in this paper show that, in certain positions on the aeroplanes tested, very large accelerations, up to $8 g$, occur on landing.

The calculation of the speed at which flutter may be expected to occur in an aeroplane wing has for some time exercised the minds of aeronautical engineers. In the present volume W. Barrois, J. Simon-Suisse and their colleagues give an account of the numerical methods used in France in making these calculations. They also describe electrical analogues which can be used in this connexion. Among the purely experimental papers, one by C. Mylonas on the distribution of stress in glued joints opens new ground. The stresses in the transparent glue are determined by photo-elastic methods.

The high quality and great variety of the papers in these volumes provide evidence that the science of applied mechanics has plenty of vitality, and that it is attracting the attention of many young people, as well as holding the interest of the older workers. The Congresses for Applied Mechanics are usually held at four-year intervals, and the next one will take place in Istambul in $\mathbf{1 9 5 2}$.

\section{COMMONWEALTH CONTRIBUTIONS TO THE BRITISH DIET}

$T$ HE Nutrition Society, at its meeting in the London School of Hygiene on January 28, discussed what the British Commonwealth could do to feed Great Britain. In the morning session representatives from those Dominions which are the principal contributors to the British diet, and representatives of the West Indies and the Overseas Food Corporation gave the meeting details of what they are already contributing and what they may be able to do in the future. In the afternoon, the morning papers were discussed, commodity by commodity, by British experts on various foodstuffs. A most valuable symposium resulted.

The meeting opened with a paper by Lieut.-Colonel J. G. Robertson, speaking on behalf of Canada. His Dominion, he said, is the second largest country in the world, but it has a population of only about thirteen and a half million people; it is therefore a large exporter of food. He explained in some detail the remarkable contribution which Canada made to the solving of the British food problem during the Second World War. To do this she greatly increased her production of many foods. In 1938 she exported 160 million lb. of bacon, and by 1944 she was exporting 660 million lb. to Britain ; cattle marketings were virtually doubled, and Cheddar-cheese production increased by 58 million lb. Canada has also sent a considerable variety of foods to Britain, including wheat, flour, bacon and hams, beef, mutton and lamb, poultry, eggs (shell and dried), cheese, evaporated milk and milk powder, fruit, vegetables, lard, salmon, honey and maple products.

Colonel Robertson also pointed out that during the war years Great Britain found it impossible to pay for all her war expenditure (arms, equipment and so forth) and still meet the bill for her food supplies. Canada helped her unstintingly in the financial field by making gifts of more than two thousand million dollars and interest-free loans of more than one thousand million and also by conversion of certain British assets in Canada into cash to the tune of some four thousand million dollars. So by these means during the War, Great Britain was able to obtain most of her food imports from Canada without actually paying for them. It is important, in appreciating the great effort made by Canada to help Britain during the War, to realize how unfortunate is the dollar position to-day, which forces Britain to buy in scft-currency markets, and to leave a food industry in Canada, greatly expanded to meet the mother country's war-time requirements, with virtually no markets for many of its products.

The Canadians are also faced with the sight of dollars provided by Marshall Aid being compulsorily spent in the United States on foods which Canada has in abundance for export. In recent years, Canada has added millions of acres to the area of grain production by the development of early maturing varieties of wheat and by creating new varieties of rust-resistant wheats. In this way she has made possible the addition of hundreds of millions of bushels to the cereal supply of the world. Given a proper incentive, the Canadians could divert their food production into whatever channels that are required. For example, they could decrease beef production and increase pork products; they could increase wheat acreage at the expense of oats, barley 
and rye, and so on. In fact, Colonel Robertson gave the meeting a picture of Canada as a country stacked with surplus wheat, cheese, butter, bacon and hams, eggs, beef, apples, preserved fruits, salmon-a list to make British austerity mouths water-and inhibited only by the barrier of dollar exchange from pouring these dietetic treasures into British laps.

Australia's contributions to the British table were described by Mr. A. H. Heywood, of the Australian Meat Board. Here no dollar difficulties arise, and we find that in the ten months ending in October 1949 Great Britain received from this Dominion $1 \frac{1}{4}$ million cwt. of butter, nearly 400,000 ewt. of cheese, 80,000 cwt. of processed milk, more than twelve million dozen eggs, more than 3 million cwt. of meat (including poultry and rabbits), about 20 million cwt. of cereals, nearly 5 million cwt. of sugar, and more than 700,000 cwt. of dried and canned fruits, not to mention nearly a million gallons of wine. Gargantuan as these quantities of food are, few of the items represent more than twenty per cent of the total import of these particular commodities. Australia also sends miscellaneous products such as edible tallow, copra, whale oil and other fats, fruit juices, jam, tomato products, cakes and puddings. The volume of fruit cake and Christmas puddings exported to Great Britain last year was very great$£ 1$ million worth of fruit cake, together with eight million Christmas puddings. Another significant contribution which Australia makes to the British diet is in food parcels, the price of which is subscribed by the Australian people and therefore costs the recipients nothing. During $1940-48$ more than eleven million gift parcels were sent to Great Britain from Australia. The parcels vary between seven and eleven $\mathrm{lb}$. each in weight, and they are still being sent at a yearly rate of about three million. In fact, the parcels use so much meat in the tinned meat which is included in them that the Australian authorities are a little uneasy about the effect of the subtraction of the large amount of meat involved from the normal export channels.

Australia could increase the amount available for export of many of the foods which she sends to Britain ; but Mr. Heywood told the meeting that it is in the production of meat that Australia is being looked upon to make the greatest contribution to the diet of Great Britain, which, he remarked, is by tradition a nation of meat eaters, though the meat producers of Australia are a little disturbed by the possibility that the extended rationing of meat in Britain may produce a generation which has lost its taste for meat. The export surplus of mutton and lamb from Australia is largely dependent upon the price of wool. The high prices for this commodity which have prevailed in recent years (due to the fact that the rest of the world still turns to Australia for about two-thirds of the total requirements for fine wool) has caused a rise in the sheep population from its low level of 96 million in 1946 to about 110 million now. Thus it would appear that a great increase in the production of mutton and lamb is possible in the near future. Nevertheless, it is in the increased production of beef that the best prospects are presented. There are vast areas in Australia which, because they are not suitable for the production of wool, remain to be developed for cattle. This is a long-term process; but measures to stimulate production in the near or immediate future are being actively promoted.

Dr. C. Hopkirk dealt with New Zealand's food contributions. This Dominion does not export grain, but in dairy products she makes a major contribution, sending in 1949140,000 tons of butter and ninety thousand tons of cheese. In 1948 the United Kingdom's imports from New Zealand represented (as percentage of the total imports) butter, 50 ; cheese, 53 ; lamb, 65 ; and mutton, 77 ; the figure for beef, however, is only 17 per cent. New Zealand is at the moment in a period of seven-year agreements with Britain, of which five years have still to run. Within the scope of this agreement the Dominion is aiming at an annual increase of two per cent of dairy products and an increase of fifty thousand tons of meat. To some extent, of course, this projected increase is governed by the seasons. It so happens that the year 1949 was the best year known for dairy products. In general, the future for increased food production in New Zealand is bright, and there is every possibility that the targets set will be achieved or even exceeded.

The case for South Africa was put forward by Mr. A. P. van der Post. The Union is not, he said, naturally a rich agricultural country, and even to-day is dependent for its bread upon the importation of wheat. There are a great variety of climate and great vicissitudes of Nature. The type of sheep found in South Africa is not the mutton-producing type, and mutton and lamb are, therefore, not to-day sent to Great Britain; nor is beef, since the Union lacks natural vegetation on which the beef cattle can be 'rounded off'. Butter used to be exported to Great Britain in small quantities before the Second World War; but drought and increased local demand in recent years have accounted for all of the Union's production of this commodity. Before the War the Union sent 4-6 million dozen eggs to the United Kingdom, a relatively small proportion of the total imports ; but they arrived at a time when supplies from other sources were scarce. It is hoped to inerease egg supplies again. It might be possible to supply pork and pork products again, if supplies of maize for use as a feeding-stuff can be assured. The Union supplies substantial amounts of whale oil to the United Kingdom, and an important post-war industry is the production of fish liver oils. Union fish-canners hope eventually to provide greater variety of canned fish for export. Sugar is also exported to Britain, and fruit and fruit products (for example, jam, marmalade, canned and dried fruit, fruit pulp and fruit juices) can be supplied in substantial amounts. Mr. van der Post felt that while the Union cannot hope to equal the record of certain other countries in the supply of large quantities of basic foodstuffs to the United Kingdom, it nevertheless can make a substantial contribution partly in basic and partly in semi-luxury foodstuffs to give variety to the British diet.

Dr. L. F. Wiggins spoke on the West Indian contribution to the British diet and pointed out that, although it sends bananas, cocoa, citrus fruits, coconuts, tinned fruit juices, tomatoes and rum, its main contribution is, of course, sugar. He spoke of the economic difficulties produced by the rapid increase of the West Indian population and stated that one way of increasing the prosperity of the various islands which make up this Colony would be to create new industries based on sugar. Reference in this connexion may be made to the food yeast factory which was set up there. A large variety of organic acids can also be produced from sugar, and also substances such as potassium acid saccharate, which can be used as a substitute for cream of tartar. 
The work of the Overseas Food Corporation was outlined by Mr. N. R. Fuggles-Couchman, who remarked that a great deal of publicity has been given to the difficulties met with in connexion with the groundnut scheme, but very little to the very successful sorghum-growing activities centred in the north-east State of Australia, Queensland. $\mathrm{He}$ pointed out that it is intended to sow groundnuts in Africa in rotation with other crops such as sunflowers, sorghum and so on, and possibly soya beans. Oil-palm cultivation on a large scale has not been undertaken because of the long period (about seven years) before any return can be expected. It is hoped in the not too distant future to provide an annual oil production of about 57,000 tons, which is still only a little more than a tenth of the estimated deficiency. of fats. In Queensland 480,000 acres of land have been purchased since March 1948, and it is proposed to grow sorghum, sunflowers and soya beans and other crops for export to Britain. Pigs and store-cattle are being fattened on sorghum to provide extra bacon and meat. It is also proposed to export sorghum direct to the United Kingdom, where it can be used for fattening stock on the spot.

During the afternoon of the meeting, various commodities were discussed as follows : meat, Dr. John Hammond ; fruit, Dr. R. G. Tompkins ; coreals, Dr. Albert Green; dairy products, Dr. E. C. Capstick; fats, Dr. C. H. Clarke; bacon, Dr. E. C. Callow; and sugar, Mr. Phillip Lyle. It is impossible to discuss the remarks of these speakers in any detail, but reference may be made to one or two items of interest. Dr. Hammond, for example, pointed out that Great Britain is more dependent now (fifty-five per cent) on overseas meat than before the War, and that the home production of pigs contributes virtually no pork, since all the carcasses are converted into bacon. Dr. Green said that Australian wheats are surprisingly low in protein, and that the protein value of Canadian wheat depends upon whether it comes from the west or east coast. The former contains one per cent less protein, and if, for example, Britain obtained all its Canadian wheat from the west instead of the east, it would cost the public 45,000 tons of protein in a year.

As Dr. Callow pointed out, the Commonwealth supplies of bacon last year represent only about eighteen per cent of the total requirements, and if it is assumed that the present bacon ration in Britain remains at $5 \mathrm{oz}$. for a year, the Commonwealth contribution, if it does not increase, will represent only ten per cent of the requirements. The difference can only be made up by increased home production or further imports from outside the Commonwealth. Dr. Tompkins said that fruit consumption in Great Britain has fallen from $92 \mathrm{lb}$. per head before the War to $76 \mathrm{lb}$. now, of which half is home grown. Dr. Capstick thought that the Dominions had done a wonderful job during the War in helping with the varying demands in Britain for dairy products. $\mathrm{He}$ said that the present market is more or less saturated for the type of cheese now being supplied, and that Commonwealth cheese makers might consider shipping varieties other than Cheddar. Another point of interest which he made is that sixty thousand tons annually of pre-war butter in Britain came from eountries which are now behind the 'iron curtain', and that this has to be made up from other sources.

The meeting was reminded by Dr. C. H. Clarke that there is a world shortage of oils and fats. Although the per capita availability of fat for edible purposes is about equal to pre-war, there is a considerable shortage of soap. Greater use of detergents would not free more fat for food because only lowgrade fats are used for soap making. Whale oil at the moment can only be used for food purposes. Hydrogenation provides us with a means of obtaining an enormous variety of fats and oils. Mr. Phillip Lyle said that increased production of sugar in the West Indies comes, not from planting more extensive areas, but by more intensive and improved methods of cultivation of areas already planted. He said that, although the food yeast factory is a good idea, it is difficult to persuade West Indians to eat its product. Some of this is being sent to Great Britain and is sold to manufacturers. The cause of the rise in prices is that there is not sufficient demand for the product to keep the factories working full time.

Dr. W. K. Slater (chairman) wound up an admirably conducted meeting by stressing the difficulties that will arise in feeding the British population as increased home demands are made for various foodstuffs in the countries producing them, and which at present have an exportable surplus that is sent to the United Kingdom.

\section{NEWS and VIEWS}

\section{North Staffordshire University College: First Appointments}

THE following full-time professors have been appointed in the new North Staffordshire University College which is to be opened in August at Keele, near Newcastle-under-Lyme: Mr. W. B. Gallie, senior lecturer in philosophy, University College, Swansea (philosophy); Mr. A. E. Teale, lecturer in philosophy, University of .Manchester (political and moral philosophy); Mr. I. N. Sneddon, lecturer in natural philosophy, University of Glasgow (mathematics) ; Dr. H. D. Springall, senior lecturer, University of Manchester (chemistry); Mr. J. W. Blake, senior lecturer in history, Queen's University, Belfast (history); Mr. J. J. Lawlor, lecturer in English in Brasenose and Trinity Colleges, Oxford (English); Mr. W. W. Chambers, lecturer in German, University of Leeds (modern languages); Mr. S. E.
Finer, tutor and research fellow, Balliol College, Oxford (political institutions); Mr. S. H. Beaver, reader in economic geography, London School of Economics (geography); Mr. B. R. Williams, lecturer in economics, Queen's University; Belfast (economics); Dr. V. A. Vick, senior lecturer in physics, University of Manchester (physics) ; Dr. A. R. Gemmell, lecturer in botany, University of Manchester (biology); Mr. W. Stewart, lecturer in education, University College, Hull (education).

\section{Inland Water Survey Committee}

THE Minister of Health, Mr. Aneurin Bevan, and the Secretary of State for Scotland, Mr. Arthur Woodburn, have reconstituted the Inland Water Survey Committee, with membership as follows: MajorGeneral G. Cheetham (chairman), Mr. R. H. Cuthbertson, Mr. A. A. Fulton, Mr. W. H. Haile, Mr. M. G. 